Cahiers $d u$ MONDE RUSSE

\section{Cahiers du monde russe}

Russie - Empire russe - Union soviétique et États indépendants

Foreword

\title{
Communications and media in the USSR and Eastern Europe
}

Kristin Roth-Ey and Larissa Zakharova

\section{(2) OpenEdition}

\section{Journals}

Electronic version

URL: http://journals.openedition.org/monderusse/8182

DOI: $10.4000 /$ monderusse.8182

ISSN: $1777-5388$

\section{Publisher}

Éditions de l'EHESS

\section{Printed version}

Date of publication: 17 April 2015

Number of pages: $273-289$

ISBN: 978-2-7132-2476-8

ISSN: $1252-6576$

\section{Electronic reference}

Kristin Roth-Ey and Larissa Zakharova, « Communications and media in the USSR and Eastern Europe », Cahiers du monde russe [Online], 56/2-3 | 2015, Online since 17 November 2019, Connection on 22 September 2020. URL : http://journals.openedition.org/monderusse/8182 ; DOI : https://doi.org/ $10.4000 /$ monderusse. 8182

This text was automatically generated on 22 September 2020

(c) École des hautes études en sciences sociales 


\title{
Foreword
}

\section{Communications and media in the USSR and Eastern Europe}

\author{
Kristin Roth-Ey and Larissa Zakharova
}

1 Communications in socialist Europe have long been associated first and foremost with propaganda. The USSR-the world's first "propaganda state," to use Peter Kenez's term - established a radical new communications order that would be widely emulated. "The Bolshevik regime," wrote Kenez in an influential 1985 study, "was the first not merely to set itself propaganda goals but also through political education to aim to create a new humanity suitable for living in a new society." ${ }^{1}$ Propaganda, in this sense, had no strictly delimited "political" sphere of operation in the Soviet/socialist context; on the contrary, it was embedded in all aspects of cultural, social, and economic life. Propaganda was also, it bears emphasizing, devoid of dismissive ("mere propaganda") and negative (propaganda-as-brainwashing) connotations in the new lexicon-at least when applied to the socialist context. Propaganda in socialist hands was celebrated as an essential, progressive tool of socialist modernity. Communications in support of propaganda diffusion-from the early agitpoezdy and posters to publishing and broadcasting, film, theater, and so on-received major support from the hard-pressed "propaganda state."

Beyond the Soviet Union, the relationship between propaganda and public, or popular, opinion $^{3}$ has preoccupied observers since at least the1920s, when thousands of foreigners travelled East to learn what made the socialist state and society tick, and when the Soviets themselves began an expansive and, in many regards, innovative program of cultural diplomacy. ${ }^{4}$ The question of whether Soviet propaganda "worked" was thus a foundational one in the West, invested with hopes and fears alike. As the cold war heated up in the late 1940s, the problem of propaganda- now often discussed in terms of state-sponsored "psychological" (or "political") warfare- gained even greater force. ${ }^{5}$ The main lines of what would later be dubbed a "totalitarian" school in Soviet studies presented a model of the Soviet regime as resting on the dual pillars of propaganda and repression or, in Lenin's terms, "on a balance between coercion and 
persuasion." The growing atomization of society-the suppression of horizontal ties of communication and enforced dependence upon vertical ones-was said to guarantee the persuasive power of Soviet propaganda. In this way, a tool initially designed to promote social cohesion corroded social bonds, an instrument of enlightenment was in fact a weapon of manipulation, immobilization, and pacification.

The opening of the archives in the 1990s shattered whatever image of a Soviet society utterly pacified and atomized had endured. But in truth, the so-called "totalitarian" school was always far less one-dimensional than its contemporary reputation implies. The work of social scientists Alex Inkeles and Raymond Bauer (from the Harvard Project on the Soviet Social System), to take one example, makes liberal use of terms like "indoctrination," "conformity," and "control"; indeed, the title of their best-known study, The Soviet Citizen: Daily Life in a Totalitarian Society, puts the offending term "totalitarian" front and center. ${ }^{7}$ Yet for all that, to read Inkeles and Bauer is not to get the sense of a brutalized and brainwashed Soviet mass, but rather of a dynamic, even demanding population. (Their use of the term "citizen" is worth emphasizing.) Inkeles and Bauer note repeatedly the extent to which Soviet citizens support core socialist ideas (such as a welfare state) and illiberal values (restrictions on freedom of expression, for example). These Soviet orientations are broadly attributed to the impact of the "communications system" : their answer to the perennial question "does Soviet propaganda work ?" was in this sense "yes," and they made it clear that they did not approve. We may, if we wish, judge them for their judgment. But Inkeles and Bauer, however partisan, were also able to detect and report on the many ways in which Soviet communications did not work-or at least not in any simplistic, "transmission belt" model of Leninist theory. Soviet citizens were, they said, capable of evaluating media messages and sizing up their leaders' commitment to them.

What Inkeles and Bauer thought they saw in the Soviet Union was a modern and modernizing society that had much in common with other modern societies, meaning institutions like mass higher education and mass media, but also values-an emphasis on personal well-being and peer-orientation. It was a theme picked up and developed by other social scientists in the 1960s, 70s, and ' 80 s, mostly importantly, Ellen Mickiewicz, whose pioneering studies of Soviet media portrayed a complex and sometimes contradictory communications system in relation to an equally complex and restive audience. ${ }^{8}$ The terms of reference may have remained the same - "indoctrination," "malleability" and so on-but the image of Soviet society was anything but static, as was that of communications and media. In 1990, S. Frederick Starr, a historian, analyzed the Soviet communications system in the tradition of the centralizing autocratic Russian state, using the familiar horizontal/vertical framework : Soviet leaders, like their tsarist predecessors, promoted vertical ties and suppressed horizontal ones. But critically, Starr also showed how wide of the mark Soviet communications had been-how ineffective, that is, at both tasks and, above all, the suppression of horizontal ties, which, he noted, grew increasingly difficult with the political, sociological, and technological shifts of the post-Stalinist era. ${ }^{9}$ In this way, studies ostensibly focussed on propaganda opened avenues to research on the complexity of communications practices and the plurality of media publics in the USSR.

5 The opening of the archives helped to further develop the idea of the vitality of Soviet society, including its communications practices, long before 1953. Studies of letters written to the authorities and to the press have demonstrated that, even under Stalin, 
vertical communications operated not only from top to bottom, from regime to mass, but also in the opposite direction..$^{10}$ Horizontal, or interpersonal, communication, however, has attracted less scholarly interest. ${ }^{11}$ This special issue seeks to fill this gap and to address the variety of different forms of communication in the USSR and socialist Europe.

With the new material and approaches now available, historians can question anew the fundamentals of social life in the USSR and Eastern Europe. Above all, we are interested in examining the nature and characteristics of social bonds, defined as forms of solidarity and cohesion that exist in every society, with or without the mediation of state structures. ${ }^{12}$ Communications practices (both direct and mediated) can offer a prism through which to evaluate the strength of social ties and understanding. And to do this, we need to take account of what our historical actors tell us and consider their words as forms of engagement, rather than dissimulation.

7 To be sure, the very fact of the Bolsheviks' monopoly on communications has had a powerful and, some might say, distorting effect on the way scholars have conceived of Soviet society and public opinion. For one, the orchestrated, didactic nature of Soviet media (what Jeffrey Brooks called a "performative" public culture) meant that many scholars long wrinkled their noses at media sources as unreal and unreliable-void of valid information about society, particularly for the Stalin period. ${ }^{13}$ It is the authoritarian regime itself, with its aim to present a wholly unified society, that put historians in this bind. And as a result, the historiography has tended to cluster around two poles : the first, a mirror image of the regime's own ideal of unity, but with the values reversed (yes, there was unity : everyone secretly resisted, as in Sarah Davies's work) ${ }^{14}$ and the second, a portrait of the regime as having been largely successful in its efforts to construct a unified Soviet worldview (as in the work of Jochen Hellbeck, Jeffrey Brooks and, in their way, "modernization" school social scientists like Inkeles and Bauer). ${ }^{15}$ Yet the categories of "resistance" and "support," or "belief" and "disbelief," are in themselves inadequate to the task of analyzing authoritarian socialist societies. The majority of people made their lives between the poles and occupied varied positions in relation to them over the course of a lifetime.

In recent years, the burgeoning literature on the Khrushchev and Brezhnev eras has had the diversity of the socialist experience, the multiplicity of its social milieux, and the ambiguity of its public culture as guiding themes. ${ }^{16}$ It is true that the major sociological shifts of the post-Stalinist era (urbanization and rising living standards chief among them) played a critical role here. But diversity of experience and opinion was not limited to the post-Stalinist era. By the same token, the loss of the constative dimension of official discourse with Stalin's death did not signal the end to all popular engagement with the values of the regime : as Alexei Yurchak has demonstrated, it was possible to be at once a Komsomol member and a heavy metal fan. ${ }^{17}$ We need to confront the epistemological challenge of seeing unanimity everywhere and understand that a multiplicity of opinions is not only to be found in democratic regimes, but also authoritarian ones. The difference is in the modes of expression for this multiplicity and in their legibility. 


\section{From the sociology of public spheres to the grammar of common places}

9 A diversity of opinion is one part of the classical definition of the public sphere as formulated by Jürgen Habermas ${ }^{18}$. The applicability of this concept to socialist societies has been the subject of controversy. At first glance, it seems paradoxical to speak of a public sphere-or even to draw a separation between the private and the public-in societies of the Soviet type. ${ }^{19}$ The very first thing to note when thinking about the binary public/private in the Soviet Union and Eastern Europe is the state's interference in all areas of life. From the point of view of the Bolsheviks, the private sphere deserved no autonomy; everything, including intimacy, should be placed under the vigilant control of the collective. ${ }^{20}$ The term "private," associated, as it was, with bourgeois society, was replaced by "personal." (One spoke of "personal" rather than "private" property in Soviet society.) The "public" was identified with the "common" or "communal." And on this basis, at least in theory, in place of opposition, the public versus the private, stood complementarity, the communal and the personal. ${ }^{21}$ Some scholars have thus proposed terms such as "quasi public sphere" or "public privacy" for Soviet-type societies where, in their view, all the typical traits of the public spherefreedom of expression, open debate, and the opportunity to influence politics-were absent. $^{22}$

10 A related tendency in the historiography relevant to our interest in communications has been to insist upon the distinction between "official" and "unofficial" cultures in socialist states. In the Soviet context, Jeffrey Brooks offered a sweeping analytical study of Pravda as the best example of what he called "official public culture" implicitly distinguished from, and opposed to, an unofficial, private culture. Brooks described this "official public culture" as "eclectic" but so "constricting" in its content, and so false as to be damaging to the development of Soviet consciousness. The press created "a stylized, ritualistic, and internally consistent public culture that became its own reality and supplanted other forms of public reflection and expression." ${ }^{23}$ Much of what we might call the "first wave" of work on the rock music and youth culture under socialism also relied on a distinction between an authentic unofficial sphere and a false official one, as of course have many analyses of samizdat and dissent. These concepts are in fact native to a Soviet/socialist context : the valorization of the "authentic" (the "sincere") and, by association, the equation of the unofficial with the real, was a central operation of the post-Stalinist Thaw. But a rallying cry, however compelling, is no proof of analytical validity. As more recent studies of, in particular, Brezhnev-era culture, have shown, the borders between official and unofficial socialist cultures could be porous indeed..$^{24}$ Lewis Siegelbaum, in his introduction to the recent collection Borders of Socialism: Private Spheres of Soviet Russia, identifies a similar interplay in the categories of public and private themselves; in place of two, separate spheres, "hermetically sealed" off from one another and perforce in opposition, Siegelbaum proposes the private "in dynamic, interactive tension with the public, itself understood as a complex, multi-layered category." ${ }^{25}$

11 References to the bourgeois public sphere in work on socialist societies point to the fact that many scholars see the concept in normative terms, as an ahistorical ideal-type. ${ }^{26}$ Yet Habermas himself warns against this in the introduction to his book on the public sphere, cautioning readers that it is impossible to construct an ideal-type from the 
public sphere as it manifested itself in the high middle ages. He distinguishes four types of public sphere corresponding to four different historical moments: 1) the representative public sphere of the high middle ages) ; 2) the bourgeois liberal sphere, which was literary in nature, referring to a public of individuals who operated by reason, tightly related to the reading practices and sociability of the Enlightenment; 3) the illiterate, plebeian sphere that rose as a consequence of the bourgeois revolutions of nineteenth century, and ; 4) the condition of plebiscitary acclamation, applicable to twentieth-century societies, which is post-literary, meaning dominated by opinion in the absence of public discussion. ${ }^{27}$

Historians of the USSR have sought to confront Soviet sources and empirical evidence with the concept of the bourgeois public sphere, and as a result, two definitions of the public sphere, narrow and broad, have been put forward. In the first, narrow definition, the public sphere is equated with the Soviet concept of obshchestvennost' (regime activists or militants meant to represent "orthodox" public opinion). ${ }^{28}$ The second, broad definition concerns a multitude of practices and formal and informal social spaces (including corners of resistance and dissidence. . $^{29} \mathrm{By}$ addressing ourselves to the last part of Habermas's argument devoted to the decline of the bourgeois public sphere, we can reconcile these two definitions and distinguish three types of public sphere in socialist societies: 1) a public sphere of plebiscitary acclamation, purely official in nature, corresponding to Soviet obshchestvennost ${ }^{\prime} ; 2$ ) a semi-controlled public sphere that provided opportunities to outmaneuver control through the formal frameworks that ensured its existence. ${ }^{30}$ (It was these semi-controlled spheres that underwrote the regime's longevity. This was the realm of camouflaged critique, using coded language and references accessible only to insiders.) 3) Pockets of opposition to the state that were openly critical and illegal. ${ }^{31}$

13 This issue of Cahiers presents three articles that utilize the concept of the public sphere. Stephen Lovell associates it with the introduction of shorthand in Russia in the 1860s in the context of the emergence of new institutions under Alexander II-zemstva and open courts-that enlisted individual participation in political life. To document the spoken word in print form was something that resonated with contemporary demands for publicity. Subsequently, the Bolsheviks themselves came to rely heavily on stenographic reports, which they considered important mediating instruments in public life. However, economic considerations worked in favour of minutes rather than complete stenographic records, as did the growing practices of secrecy. Increasingly corrected and censored, stenograms were transformed as a communications tool and marginalized from central decision-making practices, notably in the Politburo. Ultimately, shorthand can be seen as a technology that put Bolshevik democracy to the test.

Roman Krakovský interrogates the specificity of the socialist public sphere by studying the functions of the local council in a small Czechoslovak city on the outskirts of Prague. In particular, he is interested in understanding whether this institution succeeded in conceptualizing and defending an idea of the common good. His conclusion is that it did not. Krakovsky shows that, despite the common practice of writing to the authorities to resolve personal problems or denounce community members, public participation in council meetings grew increasingly formal; the individual was subordinated to the collective, and the meetings served above all to transmit information in one direction and to mobilize the population. As a result, 
individuals grew ever more isolated from one another, and though alternative spaces for discussion and sociability did exist, they never managed to define the common good. Fundamentally, as defined by the Czechoslovak communist party, the common good was a mechanism for increased social control enacted via denunciations and shrinking individual autonomy.

Kirsten Bönker reaches very different conclusions in her study of television in the Soviet Union. By examining the summaries of viewer mail produced by Central Television professionals under late socialism, Bönker demonstrates the ways in which television transformed political communication. Even if only $3 \%$ of viewers wrote to the television administration, their correspondence worked to justify the medium's social function in the eyes of the authorities. The author argues that television contributed to the connection between the private and public spheres in so far as the public, via programming, entered into the private realm and nurtured interpersonal communications; at the same time, media coverage of viewer letters to Central Television made private concerns public. According to Bönker, television contributed to a sense of belonging and was for this reason a factor in the regime's stability.

The difference in these two interpretations relates in part to the nature of the evidence they use. Which sources can we access to study the diversity of public opinion? Which tools can we use to generate a sociology of the Soviet public(s)? The plebiscitary acclamative sphere (as defined above) is the simplest to access because it is the best documented in minutes and stenographic reports of official meetings. The semi-controlled sphere demands greater ingenuity of the researcher; here we must cross-reference official sources related to the supervision of this sphere by party and state organs with less formal documents often located in personal archives. The oppositional sphere is accessible via official documents relating to the persecution of dissidents, on the one hand, and samizdat materials and collections of personal documents, on the other.

17 A number of Soviet historians have approached the problem of public opinion by looking at rumors. ${ }^{32}$ Because rumors can only spread widely where people are not subdivided into separate enclaves, their dissemination offers a window on the nature of any given society. At a macroscopic level, it is weak ties linking different communities together that promote social cohesion. Individual social mobility helps build bridges between different communities provided that the society also has tools for communication across distances: $:^{33}$ "any message can reach a greater number of people and cover a larger social distance (that is, route length) if it is transmitted via weak links rather than strong ones. ${ }^{{ }^{34}}$ But most works about rumor in the Soviet context rely primarily on reports from the secret police (svodki) on the mood of the population-a source with well-documented analytical weaknesses. ${ }^{35}$

Other Soviet historians have utilized letters to the regime (pis'ma vo vlast') as a means to investigate popular moods. However, given that denunciations and complaint letters were used by the authorities for repressive ends, enabling them to target supposed enemies, the use of these letters as a source on public opinion has also been a subject of historiographical debate. To be sure, although letters allow us to form some idea of the variety of opinions in the population, they can only offer a restricted and partial view. It was unusual for someone to feel so involved in the life of the country as to send a letter to the authorities. ${ }^{36}$ Oleg Khlevniuk takes up the question of communication with the regime by examining Stalin's responses to the letters addressed to him personally. 
His study reveals the bias of Stalin's interests, which were, he finds, limited to theoretical problems in Marxist-Leninist ideology, expressions of political loyalty, and messages from former acquaintances. Other types of letters were not put forward by Stalin's office for the General Secretary's attention, and at best were used to compile reports on the situation in the country and mood of the population.

Opinion polls conducted in the late Soviet Union and comments books at exhibitions have also been used to approach the problem of public opinion, though the sincerity of the responses recorded remains something of an open question. ${ }^{37}$ Personal correspondence-above all, correspondence between intimates-was less subject to the need to conform to the conventions of official discourse, even in light of perlustration practices : censorship could motivate letter writers to adopt Aesopian language and express themselves cautiously. ${ }^{38}$ In this issue, Kirill Feferman's article shows how one Jewish family, the Ginzburgs of Rostov-on-Don, struggled to come to terms with the contradictory information available in the press and the realm of rumor in 1941. He brings out the impact of censorship on their correspondence in their use of formulaic language about the enemy and hope in imminent victory. The repeated use of the official discourse in the beginning and the end of letters, he suggests, was a technique for mollifying the censors.

It is possible to approach the problem of sources and public opinion differently if we first question the Habermasian definition of the public sphere. According to Antoine Lilti, the definition of the public sphere as something requiring the operation of critical reason is

grounded entirely in a political ideal, that of public debate projected onto the Age of Enlightenment, in order to better critique everything which takes its distance from that ideal in our contemporary world. ${ }^{39}$

In its idealization of the eighteenth century, this concept of public sphere leads us astray in our thinking of what a public could be. In his study of celebrity, Lilti demonstrated that the public:

is not only a case of literary, artistic, or political judgment ; rather, it is a set of anonymous readers who read the same books and, increasingly in the eighteenth century, the same periodicals. The public is not formed by the exchange of rational arguments, but rather by sharing the same curiosities and beliefs, by being interested in the same things at the same time and by being conscious of that simultaneity. ${ }^{40}$

21 This conceptual shift proves critical to overcoming the dichotomy between public and private in socialist states. Considered from this angle, the public becomes a body capable of exercising collective criticism (for or against the regime), but it is also a province of mass culture, with its diversity of opinions. Individuals' consciousness of constituting a public-that is, of sharing the same interests at the same timestimulates mutual imitation and opens the door to mutual influence at a distance. The role of mass media here is crucial because media circulate the messages and images that contribute to constituting the public.

Soviet leaders were highly aware of the importance of the media. Regime change in 1917 was accompanied by a communications revolution that manifested itself first in the distribution of the press throughout the country and, in time, in mass radio and television broadcasting. The Bolsheviks considered it essential to provide everyone access to the official discourse, particularly with the aim of political education. To that end, they put in place a variety of mechanisms, including extremely low pricing for 
periodicals (in relation to production costs). In the end of the 1920s, the rates were four times lower than their pre-war equivalents, while distribution volume was two and half times higher. ${ }^{41}$ Nevertheless, the history of the first half of the twentieth century demonstrates how difficult the regime found it to cover the country with communication networks. In 1947, $65 \%$ of the Soviet population lived in rural areas that held less than $20 \%$ of radio equipment. Some collective farms had no (wired) radio speaker at all. Similarly, the majority of Soviet villages were located more than ten kilometres from a post office, complicating the distribution of newspapers. Even if political educators were doing their jobs, the fact is that regime discourse was far from omnipresent in the countryside, which remained governed by mechanical solidarity (in Durkheim's definition) at least until the end of the Stalin's rule. By contrast, as of the 1950s, we begin to see dynamics strongly favoring the consolidation of media publics, most importantly, the shift from wired to wireless broadcasting, the influx of foreign radio broadcasting in the USSR, and the arrival of transistor radio and then of television, both of which enabled users to choose among programs to listen to and watch. Urbanization allowed ever increasing numbers of people to access mediated mass culture. By 1970, radio had entered every Soviet home, with 95 million radio sets across the country. While in 1950, the total number of television sets averaged out to one per twelve thousand people, in 1970, the ratio was one per fifteen, and in 1980, one per four ${ }^{42}$.

Mass culture is tightly linked to the creation of celebrities, which socialist media mastered perfectly. We need only think of the media campaigns around Aleksei Stakhanov, Iurii Gagarin and the other cosmonauts, or indeed Nikita Khrushchev, whose press photographs from the 1950s and '60s are analysed in this issue by Ekaterina Vikulina. Communication via celebrities is at the heart of the phenomenon of the media public in socialist countries. Laurent Thévenot's conceptualization of the grammar of common places and regimes of engagement allows us to better understand how individuals come to understandings while maintaining their different opinions. Common places are not obvious, and they are definitely not clichés; they are instead intermediate objects-hero figures, emotionally-charged objects, emblematic scenes from literature, poetry or theater-to which we can all refer, albeit differently according to personal affinities. ${ }^{43}$ Celebrities are the common places to which, while maintaining our differences, we can attach ourselves, basically because these common places are never opened up to critical evaluation and are never questioned. The success of Soviet propaganda in the first half of the 1930s, as analysed by David Brandenberger and Jeffrey Brooks, was directly related to the abandonment of an abstract Marxist discourse about anonymous social forces and the appearance in its stead of "ordinary heroes" (Stakhanovites, pilots, etc.) in literature and film, which increased its impact on individuals. ${ }^{44}$ People's engagement with and personal investment in these common places lent a personalized, emotional character to communications. This theoretical prism can thus help resolve the conflict between support and resistance. In order the understand the diversity of opinion at play within a single individual, we need to think in terms of situated emotional engagements rather than duplicity.

The articles by Christine Evans and Anna Fishzon in this issue can both be read through this lens of socialist common places. Fishzon examines the subversive power of Soviet children's cartoons in the Brezhnev era. Censorship in this area was less stringent; artists found a niche where certain forms of criticism of Soviet reality could be allowed. The cultural implications were important. Fishzon argues that cartoons deployed the 
values of the official ideology in such a way as to transform concepts of time and affect. A "queer temporality" focussed on the present and on desire was communicated through the medium of cartoons, whose heroes became genuine common places for Soviet viewers.

As for Fishzon, the emotions elicited by the experience of cultural consumption are central to Christine Evans's work. Soviet television programs of the Brezhnev periodin particular, the program $O t$ vsei dushi analysed here-were designed to engage every viewer on a personal level by appealing to what mattered to and moved her. The portraits of ordinary heroes and heroines on screen were supposed to convey "the Soviet way of life"-the slogan of the era. Veterans of the Great Patriotic War, "honest Soviet workers," and sovkhoz tractor drivers were all emotionally charged common places that created a sense of belonging to the same community. Soviet television's emotions were critical, argues Evans, because they "offered a way to mobilize and unify in the absence of a convincing, overarching ideology."

\section{Communications and the challenges of technological innovation}

Technological innovation was inseparable from the evolution of communications practices and related diversification of audiences. The symbolic power of modern media technologies, in particular, as interfaces between the self and the social, and between the organic body and the machine, should not be underestimated. The Soviet Union and the socialist states of Eastern Europe lauded technological progress as a domain where socialism held the advantage. In practice, the introduction of new technologies was not always straightforward and was the subject of debate between specialists and the authorities. New technologies never entirely replaced old ones, and this engendered an overlap in technological generations, or what David Edgerton has called "the shock of the old." 45

Several articles in the issue address the question of communications and technological innovation. Angelina Lucento shows how figurative painting was able to preserve its status as a premier visual medium under socialism in the face of the rising prominence of photography in the late 1920s and early 1930s. Painting's presumed emotional impact on viewers was in producing collectivist feelings-"an ocean of feeling" connecting different members of society, which photography was thought not to match. These critiques of photography stimulated its evolution. The new developed thanks to the old, in a kind of permanent competition. The reproduction of paintings by mechanical means developed in reaction to the rapid spread of photographic technology.

Ekaterina Vikulina's article resonates with Lucento's in that it examines photography's transformation in the 1950s and ' 60 s as a result of the medium's appropriation by amateurs and the influx of western imagery. Both the amateur and the western photo influenced the shooting technique of Soviet professionals, who strove to introduce greater intimacy with the subjects they photographed for the press, including party and state leaders, Nikita Khrushchev in the first instance. In press photographs, Soviet leaders now looked as if they had been taken off guard, and this worked to increase the emotional impact of the shots -a phenomenon we have already encountered in the 
studies of television and cartoons. Unlike photographs from the Stalin era, which were carefully staged and retouched prior to publication, Thaw-era shots were valued for their presumed spontaneity, sincerity, and truthfulness. Technological innovation remained a central concern because to achieve these effects required modernizing typographical equipment and cameras.

According to Vikulina, photographs of Khrushchev talking on the telephone symbolized the connection between Soviet power and the people. The article by Larissa Zakharova considers the functions of telecommunications in the Soviet Union at the end of the Second World War. The decision of Soviet leaders to modernize telecommunications technologies in the Soviet Union with the help of western companies dated to the mid-1920s. Their determination stemmed from both a desire for confidentiality and the need to rule an immense territory spanning two continents. In their view, communications technologies were tools of governance and of territorial, social, and economic control. The stakes attributed to local telephone service evolved over time: in the 1920s, the urban telephone was associated with technological progress and claimed social significance; as of the beginning of the 1930s, this communications tool was supposed to lead the campaigns for the organization and management of the kolkhoz. In this way, although the historiographical cliché maintains that authoritarian regimes never encourage the development of the democratizing tool that is the telephone because it involves reciprocal exchange (unlike the telegraph, which is a first-rate tool of command), the Soviet leadership did, in fact, encourage the development of the telephone in its social uses.

We can discern a specific chronology in conceptions of the telephone's purpose in the Soviet period. In the first period, from the revolution until 1925, telecommunications are considered primarily as instruments of government. During a period of territorial conquest, telecommunication tools must respond above all to political needs. The phone is a public tool insofar as it contributes to the management of the public sphere, which itself pertains to the state. By a decree of May 6, 1920, individual telephones could be expropriated for the use of state and party leaders and institutions. Private telephone use was now limited to free public devices available only if the lines were not in use by party-state institutions. The number of subscribers in the country declined from 232,337 in 1917 to 126,870 in 1921 (an average, then, of one telephone per one thousand people). ${ }^{46}$

31 The signing of a technical assistance contract with Ericsson in 1926 marked the beginning of the second period, when the great Soviet cities were supposed to be transformed into showcases of socialism thanks to the democratization of automatic telephony. Social- and thus private-telephone usage came to the fore. In 1926-27, the bulk of urban lines was located in large cities: Moscow (48,000 subscribers), Leningrad (41,000), Khar'kov and Kiev (almost 5000), Baku (4600) and Rostov-on-Don (3600). Altogether, subscribers in these cities represented $51 \%$ of subscribers nationwide. ${ }^{47}$

In 1934, collectivization and the rise of National Socialism in Germany brought another shift in goals : connecting kolhozes and defense institutions to telephone networks was the new priority. Thus, once again, the telephone was a public tool. What is remarkable in this third period is that the technical choice made in favor of an innovative technology, Ericsson, was suddenly questioned. After a series of trials and of controversy, punctuated by the repression of engineers and technicians, a new choice was made in favor of an automatic, step-by-step Siemens telephone system (which was 
actually an older technology than the Ericsson rotary mechanical system.) In other words, in the USSR, where political power applied pressure and intervened violently, technological developments could not proceed in a linear fashion. Reversals were possible, following changes of benchmarks and reorientations in policy about priorities in usage..$^{48}$

The Second World War highlighted the problem of innovation in the realm of telecommunications in the USSR. The direct transfer of interwar German telephone and telegraph equipment as war booty actually hindered progress in the postwar Soviet Union : it created a ten-year gap with western countries, which had begun to deploy much more advanced technologies. ${ }^{49}$ These postwar transfers primarily benefitted the country's administrative apparatus, as Larissa Zakharova demonstrates in her article about the inclusion of western Ukraine in the Soviet communication networks. Direct telephone lines between the capital of the USSR and major Ukrainian cities offered a means of control that bypassed the republic-level authorities. This control imperative, coupled with the goal of political education in the annexed territories, ensured that the western regions received "privileged treatment" in the provision of technology and equipment. The seizure of goods and equipment that accompanied the inclusion of Central and Eastern Europe in the Soviet bloc did not occur in Western Ukraine. Telecommunications technologies were expected to establish Soviet political authority in these areas, while preserving their image as "prosperous regions" in the eyes of their residents.

In the Soviet Union, telephony was again officially understood in social, relational terms in the 1970s, the fourth developmental period. Until that time, the telephone was conceived of as an administrative tool above all, available in cities, in elites homes, in communal housing or in public phone booths. The authorities strove to increase the number of booths, thereby confirming their utilitarian vision of the medium. However, individuals often subverted this goal and turned every available telephone into a tool of private sociability.

Negotiations on the purpose of communication tools also emerge in Patryk Wasiak's work. Using a social construction of technology approach, this author is interested in the research, design, and development of computer networks in socialist Poland rather than in the social implications of technological innovations. The existence of several, parallel networks projects (intended for economic management and control, the transmission of data among researchers in nuclear science, and social communication) challenges the Western conception of early IT networks as a "closed worlds" closely tied to the paradigm of the Cold War. It was the imagination of technical progress under socialism that helped to encourage horizontal communications.

The history of communications and their technologies can open up new avenues for thinking about the social, the political, and the cultural in the Soviet Union and Eastern Europe. New research on the worlds of both media professionals and ordinary media consumers directs our attention to the emotional experiences at the heart of the communications phenomenon, and thus to a far more complex relationship between the private and the public, the personal and the political than is often considered. The seeming social consensus associated with socialist regimes covered many forms of engagement with socialism's common places. The superficially static and obtuse propaganda state belied a diverse, dynamic public. 


\section{NOTES}

1. Peter Kenez, The Birth of the Propaganda State: Soviet Methods of Mass Mobilization, 1917-1929 (Cambridge, Cambridge University Press, 1985), 4.

2. The literature on Soviet culture, though vast and accomplished, has infrequently engaged with issues of media and communications as such-technologies and institutions, psychologies and social practices. One goal of this special issue is to bring these two strands together.

3. "Popular opinion" is the term preferred by some scholars in an effort to avoid the idea of civil society underpinning the concept of "public opinion" as defined by Jürgen Habermas. Jürgen Habermas, The Structural Transformation of the Public Sphere : An Inquiry into a Category of Bourgeois Society (MIT Press, 1991 ; original German publication in 1962).

4. Sophie Coeuré, La grande lueur à l'Est: Les Français et l'Union soviétique (1917-1939) (P.: Seuil, 1999) ; Rachel Mazuy, Croire plutôt que voir ? Voyages en Russie soviétique (1919-1939) (P. : Odile Jacob, 2002) ; Sophie Coeuré, Rachel Mazuy, Cousu de fil rouge : Voyages des intellectuels français en Union soviétique. 150 documents inédits des archives russes (P.: CNRS Editions, 2012) ; Michael David-Fox, Showcasing the Great Experiment: Cultural Diplomacy and Western Visitors to the Soviet Union, 1921-1941 (New York : Oxford University Press, 2015).

5. For a good overview of the literature on the US side of this dynamic (as of 2002), see Kenneth A. Osgood, "Hearts and Minds : the Unconventional Cold War," Journal of Cold War Studies, 4, 2 (2002) : 85-107 ; and his Total Cold War: Eisenhower's Secret Propaganda Battle at Home and Abroad (Lawrence, University Press of Kansas, 2008).

6. Alex Inkeles, Raymond Bauer, The Soviet Citizen: Daily Life in a Totalitarian Society (Cambridge : Harvard University Press, 1959), 7 ; See also Alex Inkeles, Public Opinion in Soviet Russia : a Study in Mass Persuasion, vol. 1 (Harvard University Press, 1958).

7. For the Harvard Project on the Soviet Social System, see http://hcl.harvard.edu/collections/ hpsss/about.html.

8. Ellen Mickiewicz, Media and the Russian Public (New York, Praeger, 1981); Idem, Split Signals : Television and Politics in the Soviet Union (Oxford : Oxford University Press, 1988) ; See also the work associated with the MIT Center for International Studies (est. 1952) on media and modernization led by Ithiel de Sola Pool, e.g. Ithiel de Sola Pool, "The Mass Media and Politics in the Modernization Process," in Lucian W. Pye, ed. Communications and Political Development (Princeton: Princeton University Press, 1963); Gayle Durham Hollander, Soviet Political Indoctrination : Developments in Mass Media and Propaganda Since Stalin (New York: Praeger Publishers, 1972) ; Rosemarie Rodgers, "Soviet Mass Media in the Sixties : Patterns of Access and Consumption," Journal of Broadcasting, XV, 2 (Spring 1971); Z. Katz, The Communications System in the USSR (Cambridge, MA : Center for International Studies, Massachusetts Institute of Technology, 1977).

9. S. Frederick Starr, "New Communications Technologies and Civil Society," Loren R. Graham, ed., Science and the Soviet Social Order (Cambridge - London : Harvard University Press, 1990), 19-50.

10. See, for example, Sheila Fitzpatrick, "Supplicants and Citizens : Public Letter-Writing in Soviet Russia in the 1930s," Slavic Review, 55, 1 (Spring 1996) : 78-105; Matthew E. Lenoe, "Letter-Writing and the State : Reader Correspondence with Newspapers as a Source for Early Soviet History," Cahiers du Monde russe, 40, 1-2 (1999) : 139-170 ; François-Xavier Nérard, Cinq pour cent de vérité : La dénonciation dans l'URSS de Staline, 1928-1941 (P.: Tallandier, 2004). Alexey Tikhomirov, "The Regime of Forced Trust: Making and Breaking Emotional Bonds between People and State in Soviet Russia, 1917-1941,"Slavonic \& East European Review, 91, 1 
(2013) : 78-118. Several edited collections of letters culled from the archives have also been published under the title Pis'ma vo vlast'.

11. Scholarly work on the literary and cinematic intelligentsia (with their enduring epistolary practices) form something of an exception to this rule, to be sure. We might also note that the showcase example in the discussion of learning to "speak Bolshevik" in Stephen Kotkin's highly influential Magnetic Mountain is, in fact, a personal letter from the wife of one locomotive driver to another. Stephen Kotkin, Magnetic Mountain : Stalinism as a Civilization (Berkeley, 1995), 219-219. For recent notable discussions of interpersonal communications, see Malte Griesse, Communiquer, juger et agir sous Staline: La personne prise entre ses liens avec les proches et son rapport au système politico-idéologique (Frankfurt am Main, et al. : Peter Lang, 2011) et Véronique Jobert, Russkaia sem'ia v vodovorote velikogo pereloma. 155 pisem iz SSSR v Man 'chzhuriiu, 1927-29 gg. (SPb.: Nestor-Istorija, 2005; Russkaia sem'ia "dans la tourmente déchaïnée...” : Pis'ma O.A. Tolstoj-Voejkovoj, 1927-1930 gg. (SPb. : Nestor-Istorija, 2009).

12. Emile Durkheim, De la Division du travail social (P. : Puf, 2013 (1930)).

13. Historians, with their lust for archival dust, were more likely to veer in this direction, though many, of course, did not. Donald Filtzer on Stalinist workers, for example. Donald Filtzer, Soviet Workers and Stalinist Industrialization: The Formation of Modern Soviet Production Relations, 1928-1941 (London: Pluto Press, 1986) and Soviet Workers and Late Stalinism : Labour and the Restoration of the Stalinist System After World War II (Cambridge : Cambridge University Press, 2002). For an outstanding example of social analysis based entirely on print media sources, see sociologist Allen Kassof's book on Soviet youth, The Soviet Youth Program : Regimentation and Rebellion (Cambridge : Harvard University Press, 1965). Notably, Mark Hopkins, an American correspondent in Moscow, was struck by the vibrancy of Soviet media in the "60s and described the press as nothing less than a "marketplace of ideas." Mark W. Hopkins, Mass Media in the Soviet Union, New York, Pegasus, 1970. The most recent work on Soviet mass journalism has also identified it as a dynamic sector. Simon Huxtable, "A Compass in the Sea of Life: Soviet Journalism, the Public, and the Limits of Reform After Stalin, 1953-1968," PhD thesis, Birkbeck, University of London. 2013 ; Simon Huxtable, "In Search of the Soviet Reader: The Kosygin reforms, sociology, and changing concepts of Soviet society, 1964-1970," Cahiers du Monde russe, 54, 3-4 (2013) : 623-642; Thomas C. Wolfe, Governing Soviet Journalism: The Press and the Socialist Person after Stalin (Indiana University Press, 2005); Stephen Lovell, Russia in the Microphone Age : A History of Soviet Radio, 1919-1970 (Oxford, Oxford University Press, 2015).

14. Sarah Davies, Popular Opinion in Stalin's Russia : Terror, Propaganda and Dissent, 1934-1941 (Cambridge : Cambridge University Press, 1997).

15. Jochen Hellbeck, Revolution on My Mind : Writing a Diary Under Stalin (Cambridge : Harvard University Press, 2006) ; Jeffrey Brooks, Thank You, Comrade Stalin! Soviet Public Culture from Revolution to Cold War (Princeton: Princeton University Press, 2000); Alex Inkeles, Raymond Bauer, The Soviet Citizen : Daily Life in a Totalitarian Society (Cambridge, Harvard University Press, 1959).

16. Anne E. Gorsuch, Diane P. Koenker, eds., The Socialist Sixties : Crossing Borders in the Second World (Bloomington : Indiana University Press, 2013) ; Denis Kozlov, Eleonory Gilburd, eds., The Thaw: Soviet Society and Culture during the 1950s and 1960s (Toronto, et al.: University of Toronto Press, 2013); Kristin Roth-Ey, Moscow Prime Time: How the Soviet Union Built the Media Empire That Lost the Cultural Cold War (Ithaca - London : Cornell University Press, 2011) ; Juliane Fürst, “Love, Peace and Rock'n'Roll on Gorky Street: The 'Emotional Style'of the Soviet Hippie Community," Contemporary European History 23, 4 (2014) : 565-587; Juliane Fürst, "Where Did All the Normal People Go ?: Another Look at the Soviet 1970s," Kritika : Explorations in Russian and Eurasian History, 14, 3 (2013) : 621-640. Polly Jones, "The Fire Burns On? The 'Fiery Revolutionaries' Biographical Series and the Rethinking of Propaganda in the Early Brezhnev Era," Slavic Review, 74, 1 (201): 32-56; Cahiers du Monde russe "L'expérience 
soviétique à son apogée: Culture et société des années Brežnev [The apogee of the Soviet experience: Culture and society in the Brezhnve years], 54, 1-2 and 3-4 (2013); Natalya Chernyshova, Soviet consumer culture in the Brezhnev era (London - New York: Routledge, 2013) ; Timothy Havens, Aniko Imre, Katalyn Lustyik, eds., Popular Television in Eastern Europe During and Since Socialism (London : Routledge, 2015) ; Susan E. Reid, David Crowley, eds., Style and Socialism : Modernity and Material Culture in Post-War Eastern Europe (Oxford : New-York, Berg, 2000) ; David Crowley, Susan E. Reid, eds., Socialist Spaces : Sites of Everyday Life in the Eastern Bloc (Oxford - New York : Berg, 2002) ; Susan E. Reid, David Crowley, eds., Pleasures in Socialism : Leisure and Luxury in the Bloc (Northwestern University Press, 2010).

17. Alexei Yurchak, Everything Was Forever, Until It Was No More : The Last Soviet Generation (Princeton - Oxford :Princeton UP, 2005).

18. Jürgen Habermas, L'espace public : Archéologie de la publicité comme dimension constitutive de la société bourgeoise, traduction de Marc B. de Launay (P.: Payot, 1978 (1962 pour la publication allemande)), 14 .

19. Michel Christian et Sandrine Kott, "Introduction. Sphère publique et sphère privée dans les sociétés socialistes. La mise à l'épreuve d'une dichotomie," Histoire@politique, 7, 1 (2009) : 1-12.

20. Gabor T. Rittersporn, Jan C. Behrends, Malte Rolf, «Exploring Public Spheres in Regimes of the Soviet Type. A possible Approach (Introduction) », in Gabor T. Rittersporn, Malte Rolf, Jan C. Behrends, eds., Sphären von Öffentlichkeit in Gesellschaften sowjetischen Typs/ Public Spheres in Soviet-type Societies (Frankfurt-am-Main : Peter Lang), 23-35, here 23 ; Deborah Field, Private Life and Communist Morality in Khrushchev's Russia. New York, Peter Lang, 2007.

21. Michel Christian et Sandrine Kott, "Introduction. Sphère publique et sphère privée dans les sociétés socialistes. La mise à l'épreuve d'une dichotomie," Histoire@politique, 7, 1, (2009) : 1-12, here 6.

22. Gabor T. Rittersporn, Malte Rolf, Jan C. Behrends, "Open Spaces and Public Realm. Thoughts on the Public Sphere in Soviet-Type Systems," in Rittersporn, Rolf, Behrends, eds., Sphären von Öffentlichkeit in Gesellschaften sowjetischen Typs, 439.

23. Brooks, Thank You, Comrade Stalin !, 247.

24. Polly McMichaels, "Translation, authorship and authenticity in Soviet rock songwriting," Translator: Studies in Intercultural Communication, 14, 2 (2008) : 201-228 ; Anna Zaytseva, "En quête d'altérité : pour une sociologie des acteurs, lieux et pratiques de la scène rock à Leningrad/ Saint-Pétersbourg dans les années 1970-2000," thèse de doctorat en sociologie sous la direction d'Alain Blum, Paris, EHESS, 2012 ; Polly Jones, "The Personal and the Political : Opposition to the 'Thaw' and the Politics of Literary Identity in the 1950s and 1960s," in Kozlov, Gilburd, eds., The Thaw : Soviet Society and Culture during the 1950s and 1960s.

25. Lewis Siegelbaum, ed. Borders of Socialism : Private Spheres of Soviet Russia (New York: Palgrave McMillan, 2006), 3

26. Gabor Rittersporn, "Reflexes, Folkways, Networks : Social Spaces in the Pre-war USSR," in Philip R. Ross et alii, eds., Loyalties, Solidarities and Identities in Russian Society, History and Culture (London, 2013), 125-139.

27. Habermas, L'espace public, 9-11.

28. Lorenz Erren, "Stalinist Rule and Its Communication Practices. An Overview," in Kirill Postoutenko, ed., Totalitarian Communication: Hierarchies, Codes and Messages (Bielefeld: Transcript Verlag, 2010), 43-65.

29. Rittersporn, Rolf, Behrends, "Open Spaces and Public Realm..."

30. Bella Ostromoukhova, "Jouer et déjouer. Construction sociale d'une jeunesse active à travers le théâtre amateur des étudiants soviétiques, 1953-1975," thèse de doctorat en sciences sociales soutenue le 6 décembre 2011 à l'EHESS sous la direction d'Alain Blum, Paris ; Anna Zaytseva, « La Légitimation du rock en URSS dans les années 1970-1980 », Cahiers du Monde russe, 48, 4 (2008) : 651-680. 
31. Here we might refer to the vast literature on dissidence. For political dissidents, see Cécile Vaissié, Pour notre liberté et pour la vôtre : le combat des dissidents de Russie (P.: Plon, 1999). On religious dissent, see Sergei Zhuk, Rock and Roll in the Rocket City : The West, Identity, and Ideology in Soviet Dniepropetrovsk, 1960-1985 (Baltimore, MD : the Johns Hopkins University Press - Washington, D.C. : Woodrow Wilson Center Press, 2010).

32. Sheila Fitzpatrick, Stalin's Peasants : Resistance and Survival in the Russian Collective after Collectivization (Oxford: Oxford University Press, 1994); Elena Zubkova and Hugh Ragsdale, Russia After the War: Hopes, Illusions and Disappointments, 1945-1957 (Armonk, NY: M.E. Sharpe, 1998); Timothy Johnston, Being Soviet: Identity, Rumour, and Everyday Life Under Stalin (Oxford: Oxford University Press, 2011) ; Igor Narskij et al., eds., Slukhi v istorii Rossii XIX-XX vekov. Neformal'naia kommunikaciia i krutye povoroty rossiiskoi istorii (Cheliabinsk: Kamennyi poias, 2011). Inkeles and Bauer also discussed the importance of rumor in The Soviet Citizen, see esp. 159-188.

33. John Urry, Mobilities (Cambridge, Polity Press, 2007).

34. Marc Granovetter, Sociologie économique (P. : Seuil, 2008), 53-54.

35. The interrogration process required agents of the political police to classify every opinion as either positive, negative, or neutral. It was permeated by a mania for hunting spies. There was thus a tendency to see evidence of opposition everywhere, to overestimate the prevalence of certain opinions, and to generalize on the basis of individual and disparte remarks. The pressure on agents during the era of repressions was such that they were required to identify enemies and meet quotas, and this pushed them to translate Soviet peoples' statements into the language of the political police that made sense to the authorities, even to fabricate certain remarks. The choice of subjects for the reports was dictated by the priorities of the regime and did not necessarily coincide with indviduals' interests. The reports say what the authorities wanted to hear, not necessarily what individuals thought. Peter Holquist, "Anti-Soviet Svodki from the Civil War : Surveillance as a Shared Feature of Russian Political Culture," Russian Review, 56, 3 (juillet 1997) : 445-450 ; “'Information Is the Alpha and Omega of Our Work' : Bolshevik Surveillance in Its Pan European Context," The Journal of Modern History, 69, 3 (1997) ; Lesley Rimmel, "Svodki and Popular Opinion in Stalinist Leningrad," Cahiers du Monde russe, 40, 1-2 (1999) : 217-234 ; Jochen Hellbeck, "Liberation from Autonomy: Mapping Self-Understanding in Stalin's Time," Paul Corner, ed., Popular Opinion in Totalitarian Regimes : Fascism, Nazism, Communism (Oxford - New York: Oxford UP, 2009) : 49-63, here 51-53; Alain Blum, Yuri Shapoval, Faux coupables : Surveillance, aveux et procès en Ukraine soviétique (1924-1934) (P. : CNRS éditions, 2012).

36. Miriam Dobson, Khrushchev's Cold Summer : Gulag Returnees, Crime, and the Fate of Reform after Stalin (Ithaca - London : Cornell University Press, 2009) : 11.

37. See, for example, Boris A. Grushin, Chetyre zhizni Rossii v zerkale oprosov obshchestvennogo mneniia [Four lives of Russia in the mirror of public opinion] (M.: Progress-Tradiciia, 2001; Susan E. Reid, "Who Will Beat Whom?: Soviet Popular Reception of the American National Exhibition in Moscow, 1959," Kritika : Explorations in Russian and Eurasian History, 9, 4 (2008) : 855-904.

38. Vladlen Izmozik, Glaza i ushi rezhima : gosudarstvennyi politicheskii kontrol' za naseleniem Sovetskoi Rossii v 1918-1928 gg. [Eyes and ears of the regime: State political control of the population of Soviet Russia in 1918-1928] (SPb. : Izdatel'stvo Sankt-Peterburgskogo Universiteta ekonomiki i finansov, 1995); "Perlustraciia v pervye gody sovetskoi vlasti [Postal censorship during the first years of the Soviet power]," Voprosy istorii, $n^{\circ} 8$ (1995) : 26-35.

39. Antoine Lilti, Figures publiques : L'invention de la célébrité, 1750-1850 (P. : Fayard), 17.

40. Ibid., 17.

41. Larissa Zakharova, "Concevoir l'efficacité des communications en Union soviétique (fin des années 1920-début des années 1930)," Histoire et mesure, 30, 1 (2015). 
42. Kristin Roth-Ey, Moscow Prime Time : How the Soviet Union Built the Media Empire That Lost the Cultural Cold War (Ithaca - London : Cornell University Press, 2011) ; Stephen Lovell, "How Russia Learned to Listen: Radio and the Making of Soviet Culture," Kritika : Explorations in Russian and Eurasian History, 12, 3 (Summer 2011 (New Series)) : 591-615 ; Olaf Mertelsmann, ed., Central and Eastern European Media Under Dictatorial Rule and in the Early Cold War (Tartu Historical Studies, vol. 1, Frankfurt am Main, et al. : Peter Lang, 2011).

43. Laurent Thévenot, "Voicing concern and difference : from public spaces to common-places," European Journal of Cultural and Political Sociology, 1, 1 (2014) : 7-34 ; Idem, L'Action au pluriel : Sociologie des régimes d'engagement (P. : Découverte, 2006).

44. David Brandenberger, National Bolshevism : Stalinist Mass Culture and the Formation of Modern Russian National Identity, 1931-1956 (Cambridge, MA : Harvard University Press, 2002) ; Idem, Propaganda State in Crisis: Soviet Ideology, Indoctrination, and Terror Under Stalin, 1927-1941 (New Haven - London: Yale University Press, 2011); Brooks, Thank You, Comrade Stalin !. Soviet film scholars have been at work on the celebrity/propaganda nexus for years. See, for example, the articles by Richard Taylor and Maya Turovskaya in Richard Taylor and Derek Spring, eds., Stalinism and Soviet Cinema (Psychology Press, 1993).

45. David Edgerton, The Shock of the Old: Technology and Global History Since 1900 (Profile books, 2011).

46. Larissa Zakharova, “'Le socialisme sans poste, télégraphe et machine est un mot vide de sens.' Les bolcheviks en quête d'outils de communication (1917-1923)," Revue historique, CCCXIII/4, 660 (2011) : 853-874 ; "Accéder aux outils de communication en Union soviétique sous Staline," Annales. Histoire, sciences sociales, 2, 68 ${ }^{\mathrm{e}}$ année (2013) : 463-497.

47. RGAE, f. 3527, op. 4, d. 166, 1. 23.

48. Larissa Zakharova, "Quand la politique se mêle de technologie, ou le progrès technique en contexte répressif. L'Union soviétique de l'entre-deux-guerres," in Liliane Pérez et Pilar Gonzalez-Bernaldo, eds., Les savoirs-mondes: Mobilité et circulations des savoirs depuis le Moyen Âge (Rennes : PUR, 2015), 275-286.

49. Larissa Zakharova, "Des techniques authentiquement socialistes? Transferts et circulations dans les télécommunications entre l'URSS et l'Europe (années 1920-années 1960)," Critique Internationale, 1, 66 (2015) : 19-35.

\section{AUTHORS}

\section{KRISTIN ROTH-EY}

University College, Londres

LARISSA ZAKHAROVA

Cercec - EHESS, Paris 